\title{
Effects of Lime, Manure and Kitchen Ash Application on Yield and Yield Components of Faba Bean (Vicia faba L.) on Acidic Soils of Gozamin District
}

\author{
Mekonnen Asrat ${ }^{1, ~ *, ~ M a r k k u ~ Y l i-H a l l a ~}{ }^{2}$, Mesfin Abate ${ }^{1}$ \\ ${ }^{1}$ Department of Plant Sciences, Debre Markos University, Debre Markos, Ethiopia \\ ${ }^{2}$ Agricultural Sciences, University of Helsinki, Helsinki, Finland \\ Email address: \\ mek.asrat@yahoo.com (M. Asrat), markku.yli-hailla@helsinki.fi (M. Yli-Halla),maf19200614@gmail.com (M. Abate) \\ ${ }^{*}$ Corresponding author
}

\section{To cite this article:}

Mekonnen Asrat, Markku Yli-Halla, Mesfin Abate. Effects of Lime, Manure and Kitchen Ash Application on Yield and Yield Components of Faba Bean (Vicia faba L.) on Acidic Soils of Gozamin District. Journal of Plant Sciences. Vol. 8, No. 2, 2020, pp. 17-28. doi: $10.11648 /$ j.jps.20200802.11

Received: February 26, 2020; Accepted: March 13, 2020; Published: April 17, 2020

\begin{abstract}
Liming improve the properties of acidic soils and commenly increases crop productivity. The experiment to evaluate the effect of lime, manure and kitchen ash application on yield and yield components of faba bean was conducted at Yebokla kebele in Gozamin district of Amhara Region in 2017 season. The factorial combination of $0,1.5$ and $3 \mathrm{t} / \mathrm{ha} \mathrm{lime,} \mathrm{0,2.5}$ and $5 \mathrm{t} / \mathrm{ha}$ manure and $0,0.5$ and $1 \mathrm{t} / \mathrm{ha}$ kitchen ash treatments were replicated three times and laid out in randomized complete block design. The results show shortened days to maturity was recorded from plot receiving $1.5 \mathrm{t}$ lime, $2.5 \mathrm{t}$ manure and $1 \mathrm{t} / \mathrm{ha}$ kitchen ash. The numbers of effective nodule was significantly higher at $1.5 \mathrm{t}$.lime and $2.5 \mathrm{t} / \mathrm{ha}$ manure while higher plant height was recorded from $1.5 \mathrm{t} / \mathrm{ha}$ lime and $5 \mathrm{t} / \mathrm{ha}$ manure treatments. Number of pods per plant increased by combined application of $2.5 \mathrm{t}$ manure and $1 \mathrm{t} / \mathrm{ha}$ kitchen ash while maximum number of seeds per pod observed at $5 \mathrm{t} / \mathrm{ha}$ manure. The highest seed yield $(2.59 \mathrm{t} / \mathrm{ha})$ obtained from combined used of $1.5 \mathrm{t}$ lime, $5 \mathrm{t}$ manure and $0.5 \mathrm{t} / \mathrm{ha}$ kitchen ash meanwhile maximum straw yield was recorded from $5 \mathrm{t} / \mathrm{ha}$ manure rate. The economic analysis revealed that combined used of $1.5 \mathrm{t}$ lime, $0.5 \mathrm{t}$ kitchen ash and $5 \mathrm{t} / \mathrm{ha}$ manure gave a net profit of 26,533 Birr/ha with acceptable MRR (98\%), thus this treatment is found optimum to increase crop yield on acidic soils of Gozamin district.
\end{abstract}

Keywords: Acid Soil, Amhara, Liming, Manure, Nodule, Pod, Seed Yield

\section{Introduction}

Faba bean is a highland pulse crop and a source of protein for low income group of society as it contains about 20 to $30 \%$ protein in weight basis. Besides, faba bean is the main source of income for highland farmers and contributes a great share of foreign exchange to Ethiopia [1,2]. Being a legume crop that significantly fixes $\mathrm{N}$ and increases soil fertility, it is widely used for intercropping [2, 3]. In crop rotation of faba bean and wheat, grain yield of wheat increased by $36 \%$ as compared with crop rotation in fields of barley and wheat [4]. Faba bean is the first seed legume in Ethiopia in terms of source of foreign exchange earnings [1] besides it is the leading pulse in area coverage and yield in the country, Amhara Region and in east Gojjam zone. However, the cultivation of faba bean has declined in 2013 to $2015[5,6]$ which might be due to high intensity of soil acidity and nutrient depletion. Currently, some farmers in the area grow acid tolerant crops such as wild oat or engedo (Avena abyssinica) and lupine or gebeto (Lupinus spp) at the expense of other important crops including faba bean.

As much as $95 \%$ of the cultivated land and $85 \%$ of the population of Ethiopia is found in the Ethiopian highlands. Most cultivated lands have been degraded due to inappropriate land use, torrential rainfall pattern and intensive cultivation for long period of time with low nutrient replenishment features [7, 8]. Rapid population growth in Ethiopia in general and in Ethiopian highlands in particular has increased the demand of food and fiber products and as a result it exerts pressure on environmental resources especially on land. Most soils of Ethiopian highlands 
have low level of essential plant nutrients and organic matter.

According to the report published in 1988 [9], about $30 \%$ of the Ethiopian highlands' soils are highly weathered, but now a days this coverage larger, due to high intensity of acidity. Acid soils cover nearly $40 \%$ of Ethiopia [10] and the problem has begun to be visible in the west, southern, south-western and northwestern parts of Ethiopia Acidic soils are rich in iron and aluminum oxides and upon acidification they easily release large amounts of aluminum which reaches toxic level for root growth and limits the availability of most nutrients particularly phosphorus $[11,12]$. Crop grown in acidic soils has taken up only $9.6 \%$ to $13.5 \%$ of the applied $\mathrm{P}$ fertilizer [13]. The yield of crops, particularly barley is as low as $0.5 \mathrm{t}$ $\mathrm{ha}^{-1}$ due to high intensity of soil acidity [7]. The survey conducted in northwestern Ethiopian highlands indicates that $16.2 \%$ of cultivated lands of Amhara National Regional State are categorized as strongly acidic, whereas $28.3 \%$ of the cultivated lands are moderately acidic [14]. Neither inorganic fertilizers nor organic sources alone can result in sustainable productivity [15]. Maintaining soil fertility and using plant nutrients in sufficient and balanced amounts is one of the key requirements to increase crop yield [16].

Adverse soil properties limit the availability of certain plant nutrients as a result of fixation and low decomposition of organic matter $[17,18]$. Vast areas of tropical lands that were once fertile have rendered unproductive due to continuous cultivation and erosion which has caused physical soil degradation, loss of soil organic matter and a decrease in cation exchange capacity as well as increased $\mathrm{Al}$ and $\mathrm{Mn}$ toxicity and the availability of certain nutrients particularly $\mathrm{P}$ which is decreased in low soil $\mathrm{pH}$ [13]. On the other hand, the activities of most beneficial microorganisms that are involved in the process of mineralization of $\mathrm{N}$ and biological nitrogen fixation are inhibited under acidic conditions [19].

Ethiopian highland's soils are highly acidic and depleted of nutrients and as a result productivity of the crop has decreased [10]. Faba bean is sensitive to acidic soil which requires a $\mathrm{pH}$ of 6-8 soil and the crop can grow in lower acidic saturation soil [at permissible acid saturation of 5\%, 20]. Low productivity of faba bean in Ethiopian highlands is due to several abiotic factors but the intensity of soil acidity and fertility depletion have the leading role [21]. Soil acidity is one of the major soil chemical constraints which limit agricultural productivity in the mid and highlands of Ethiopia.

Liming of acidic soil increases the $\mathrm{pH}$ of soil and as a result precipitates exchangeable aluminum (decrease $\mathrm{Al}$ toxicity) and increases the concentration of essential nutrients [22, 23]. Liming creates suitable soil environmental condition for leguminous crops as compared to cereal in terms of associated microorganisms. Liming acid soils increases the activity of nitrogen fixers, which is evidenced by significantly higher number of nodules after liming. This might have increased nitrogen fixation by groundnut and hence increased yield [24]. Although, lime application significantly improves the productivity of acidic soils it requires a huge amount of liming materials and the cost is unaffordable to poor farmers. Wood ash is used to raise $\mathrm{pH}$ in soils due to its chemical composition and content of many plant nutrients often limiting plant growth $[25,26]$. On the other hand, manure application on acid soils also increases soil $\mathrm{pH}$ but decreases the solubility of $\mathrm{Al}[27,28]$.

Improving crop production through applying high cost inputs (fertilizers and lime) is unsustainable management but integrating them with locally available low cost inputs such as manure, biofertilizer and ash has synergistic effect on sustainable production [29]. Thus, integrated use of lime with locally available materials such as manure and wood ash has great opportunity to improve the crop production for resource poor farmers. However, there is little information about the integrated effects of lime, manure and wood ash on yield response of faba bean in Ethiopian highlands in general and in the study area in particular. Therefore, this study was designed to address the following objectives.

i. To investigate the effects of lime, kitchen ash and manureapplication on growth and yield of faba bean

ii. To determine the optimum application rates of the inputfor faba bean production

\section{Materials and Methods}

\subsection{Description of the Study Area}

The experiment was conducted on a farmer's field at Kezkez gote of Yebokla kebele, Gozamin district of Amhara National Regional State (ANRS). The site is located at about $45 \mathrm{~km}$ northeast of Debre Markos town (Figure 1), The site lies geographically at $10^{\circ} 25^{\prime} 57.03$ ' $\mathrm{N}$ and $37^{\circ} 53{ }^{\prime} 37.28^{\prime \prime} \mathrm{E}$ with an altitude of 2553 masl. The experiment was carried out under rain fed conditions of 2017 main season. The study area receives about $1,344 \mathrm{~mm}$ annual rainfall and has mean annual temperature of $16.4^{\circ} \mathrm{C}$. Its rainfall characterized by uni-modal pattern which starts in the middle of June and extends to the middle of October, meanwhile peak rainfall received from mid of July to end of August. The experimental site is categorized under moist cool (M4) agro-ecology [30]. The distribution of soil types in ANRS is Luvisols, Cambisols, Leptosols, Nitisols, Vertisols, Acrisols and Regosols, respectively [31], and these soils are dominantly acidic in nature. This experiment was conducted on Nitisol soil. Engedo or wild oat (Avena sativa), wheat, barley, barley and tef, respectively are the major crops grown in the study area.

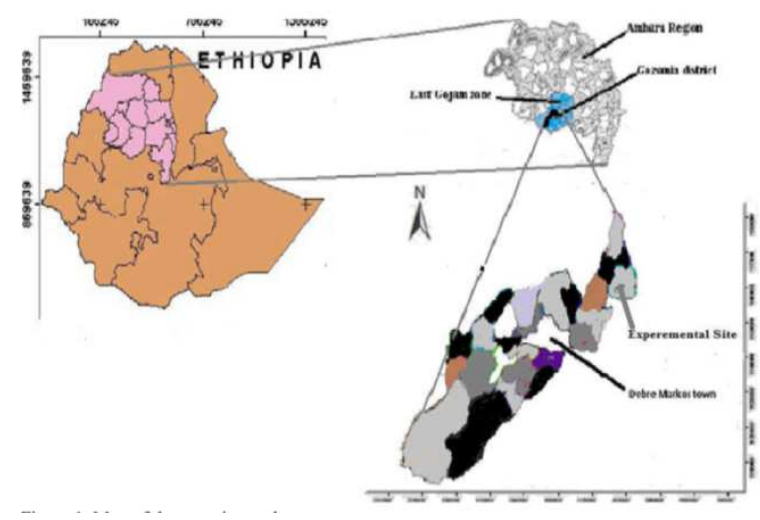

Figure 1. Schematic map of the experimental area. 


\subsection{Experimental Materials}

The test crop was faba bean, variety Walki (EH96049-2) which was released in 2008 by Holleta Agricultural Research Center (HARC/EIAR). Liming material was Dejen calcite lime with moisture content of $1.1 \%$, purity of $91 \%$, fineness factor of $52 \%$ and relative neutralizing value of $47 \%$ [32]. Kitchen ash was collected from local dwellers and sieved through $2 \mathrm{~mm}$ sieve size. The calcium carbonate equivalent (CCE) of wood ash ranged between 13.2 and $92.4 \%$ (on average 55\%) [33]. Farmyard manure was collected from ranches and decomposed for one and half month under shade to minimize the volatilization of nitrogen.

\subsection{The Physicochemical Properties of the Experimental Soil and Farmyard}

Ten soil samples were collected randomly in two-way diagonal fashion at root depth $(0-15 \mathrm{~cm})$ before crop planting and combined into two composite samples. Together with two farmyard manure samples they were transported to Bahir Dar and Debre Markos Soil Testing Libratory for the determination of selected physicochemical properties. The soil samples were air dried, ground and sieved at $2 \mathrm{~mm}$ size for the analysis of $\mathrm{pH}$, available $\mathrm{P}$ where as, for the determination of total nitrogen and organic carbon the soil was passed through a $0.5 \mathrm{~mm}$ pore size sieve. Soil $\mathrm{pH}$ was determined in solution of $1 \mathrm{M} \mathrm{KCl}$ and water with a ratio of 1.2.5 soil solution. Texture was measured by a hydrometer method [34]. Soil organic carbon was estimated through wet digestion method [35] whiles Kjeldhal procedure was used for total nitrogen [36]. Available phosphorous was extracted by Olsen method [37] and the phosphorous concentration of the solution measured by a spectrophotometer [38]. Exchangeable bases ( $\mathrm{Ca}, \mathrm{Mg}, \mathrm{K}$ and $\mathrm{Na}$ ) were extracted with $1 \mathrm{M} \mathrm{NH}_{4} \mathrm{OAc}$ at $\mathrm{pH} 7$ solution and $\mathrm{Ca}$ and $\mathrm{Mg}$ were determined by atomic absorption spectrophotometer while exchangeable $\mathrm{K}$ and $\mathrm{Na}$ were measured using flame photometer [39]. Exchangeable acidity was estimated by saturating the soil samples with $1 \mathrm{M} \mathrm{KCl}$ solution but titrated with $0.02 \mathrm{M} \mathrm{NaOH}$ [40] while its exchangeable $\mathrm{Al}$ was determined from the same solution of $1 \mathrm{M} \mathrm{KCl}$ application of $1 \mathrm{M} \mathrm{NaF}$ which forms a complex with $\mathrm{Al}$ and releases $\mathrm{NaOH}$, which was back titrated with standard solution of $0.02 \mathrm{M} \mathrm{HCl}$. Exchangeable $\mathrm{H}$ was determined by computing a difference of exchangeable acidity to exchangeable $\mathrm{Al}$.

The experimental soil was clay in texture and strongly acidic $(5.1 \mathrm{pH})$ in reaction. However, faba bean prefers soil within $\mathrm{pH}$ ranges between slightly acidic and slightly acidic [41]. Its exchangeable acidity and $\mathrm{Al}$ were 1.81 and 1.62 $\mathrm{Meq} / 100 \mathrm{~g}$ soil, respectively. Exchangeable Al becomes significant at $\mathrm{pH}$ levels less than 5.5 in water or about 4.7 in $\mathrm{CaCl}$ solution [42]. A content of exchangeable $\mathrm{Al}^{3+}$ ions above $2 \mathrm{cmol} / \mathrm{kg}$ will negatively affect growth for many crops [43]. The soil has $0.11 \%$ total $\mathrm{N}$ and $1.35 \%$ organic carbon and it was categorized under low rate, besides the soil has very low level $(0.6 \mathrm{ppm})$ available phosphorus [44]. In acidic soils phosphates tend to form stable insoluble complexes with the dissolved $\mathrm{Al}$ ions making the $\mathrm{P}$ unavailable for plants $[13,45]$.
On the other hand, it has low exchangeable cation $\mathrm{K}, \mathrm{Mg}, \mathrm{Ca}$, $\mathrm{Na}$ of $0.28,0.97,3$ and $0.01 \mathrm{meq} / 100 \mathrm{~g}$ soil, respectively.

The moisture content of farmyard manure was determined by oven-drying the samples at $105^{\circ} \mathrm{C}$ for 24 hours. The pre-determined rate of manure was adjusted using moisture correction factor [46]. The total nitrogen and available phosphorous contents of farmyard manure were estimated as per [36] and [37] methods, respectively. Its exchangeable $\mathrm{Ca}$ and $\mathrm{Mg}$ were extracted using $1 \mathrm{M} \mathrm{NH} \mathrm{N}_{4} \mathrm{OAc}$ solution and measured by atomic absorption spectrophotometer. The moisture content of the farmyard manure was 0.33 and it was slightly alkaline in reaction $(7.76 \mathrm{pH})$. The manure contained $1.82 \%$ total $\mathrm{N}, 1.6 \%$ organic carbon and $12 \mathrm{ppm}$ available $\mathrm{P}$ while exchangeable $\mathrm{Ca}$ and $\mathrm{Mg}$ were 21 and $34 \mathrm{cmol}_{+} \mathrm{kg}^{-1}$ soil, respectively.

\subsection{Experimental Design and Procedures}

The experimental field was tilled three times by oxen-drawn local plough (Maresha) then followed by manual bed preparation to obtain a fine seed bed. A gross plot size was $2 \mathrm{~m}$ $\mathrm{x} 1.5 \mathrm{~m}\left(3 \mathrm{~m}^{2}\right)$. The space between adjacent plots and blocks were kept at $0.5 \mathrm{~m}$ and $1 \mathrm{~m}$ apart, respectively. The pre-determined rates of lime and kitchen ash during the experiment set up were uniformly spread thoroughly mixed into the soil through plowing one month before crop sowing. However, the predetermined rate of farmyard manure was broadcasted uniformly on plots 15 days before crop sowing. The factorial combinations of three levels of lime $(0,1.5$ and 3 tha $\left.^{-1}\right)$, kitchen ash $\left(0,0.5\right.$ and 1 tha $\left.^{-1}\right)$ and manure $(0,2.5$ and $5 \mathrm{t}$ $\left.\mathrm{ha}^{-1}\right)$ treatments were replicated three times and laid out in randomized complete block design. The net plot was determined by excluding the outermost row from both sides of a plot and $0.25 \mathrm{~m}$ row length at both ends as border and therefore, the net size was $1.6 \mathrm{~m}^{-2}$. Faba bean was planted in row with inter-row space of $40 \mathrm{~cm}$ on July 7, 2017 at seeding rate of 175 $\mathrm{kg} \mathrm{ha}^{-1}$. The recommended $\mathrm{N}$ rate $\left(18 \mathrm{~kg} \mathrm{ha}^{-1}\right)$ as of urea $60 \%$ of the rate $\left(10.8 \mathrm{kgNha}^{-1}\right)$ was applied as starter dose while the rest $7.2 \mathrm{~kg} \mathrm{~N} \mathrm{ha}^{-1}$ was applied at tillering stage. Phosphorus fertilizer at $46 \mathrm{~kg} \mathrm{P}_{2} \mathrm{O}_{5}$ ha $^{-1}$ was applied as triple superphosphate (TSP) at sowing. All cultural practices that adopted for faba bean production were properly implemented during the experimental season. Crop data were collected from the net plot area.

\subsection{Data Collection}

The crop phenological stages (days to germinate, heading and maturity) were recorded when the crop reaches the respective stage.

a, Days to $50 \%$ emergence was determined by counting the number of days required to $50 \%$ of the plants to emerge.

$\mathrm{b}$, Days to $50 \%$ flowering refers to the days required by the plants to attain $50 \%$ flowering, identified by visual observation.

c, Days to $50 \%$ pod setting is the number of days required $50 \%$ plants attain pod setting identified by visual observation

$\mathrm{d}$, Days to $90 \%$ maturity is the number of days from sowing up to plant maturity through visual observation of senescence of the leaves as well as easily at least three pods could be quenched when pressed between the forefinger and thumb and 
when most of the pod color turns to black.

Crop growth parameters (number of effective nodules, crop height and panicle length) were measured from ten randomly selected plants from the middle rows of net plot area on proper time. The data were collected through destructive testing, so all data are of independent samples making measurements on all individuals in the population infeasible.

a, Number of nodule per plant: Bulks of the root mass carefully uprooted from randomly selected ten plants in the net plot area were collected for nodulation study at $50 \%$ flowering. It was assessed from the randomly selected five plants per plot at $50 \%$ flowering. The plants uprooted gently and washed by water. Nodules remaining in the soil were picked by hand. Nodules were removed from the plant roots and separately spread on a sieve until the water drain and then these nodules were dissected for determination of their color.

$b$, Effectiveness of the nodules was assessed based on their color. Nodules with pinkish, brown and reddish color due to leg hemoglobin presence were considered as an effective nodule while nodules with green, yellow and white color classified as ineffective in $\mathrm{N}$ fixation. The scores for nodule coloration were made in 1-3 scale, 1 scored for white, yellow and green nodules, ineffective in $\mathrm{N}$ fixation, 2 scored for pink and slightly red nodules it is moderately effective in $\mathrm{N}$ fixation, 3 scored for red and dark red nodules which is effective in $\mathrm{N}$ fixation.

c, Nodulation rating was done by carefully uprooting ten plants with intact nodules and examined for nodulation in the taproot, in the secondary roots butclose to taproot, scattered all over the roots and plants showing no root nodulation. The rating of the plants for nodulation was done in scale of 1-10. The number of plants, which have developed nodules on taproot, close to taproot, scattered over the entire roots and plants with no nodules on their root are identified and subjected to the following formula for nodulation rating [47].

$\mathrm{d}$, Plant height of randomly selected ten plants from net plot area at $90 \%$ maturity of the crop and measured from the soil surface up to the tip of the stem.

e, Number of leaves per plant stands for an average total number of leaves per plant from randomly selected ten plants on net plot area at $50 \%$ physiological maturity.

$\mathrm{f}$, Effective number of tillers was obtained bycounting the number of fertile tillers that arising from main stem at $90 \%$ physiological maturity stage. It was recorded from the randomly selected 10 plants on net plot area.

Yield and yield components parameters (pod number per node and plant, pod length, hundred seeds weight, seed, straw and biomass yield and harvest index) were measured according to the standard procedure

a, Pod number per plant was obtained by counting the total number of pods per plant from randomly selected ten plants on net plot area.

$\mathrm{b}$, Pod length is an average value of randomly selected ten plants on net plot area.

c, Pod number per node is the number of pod per node from ten randomly selected plants

$\mathrm{d}$, Hundred-seeds weightis the mean weight of randomly collected hundred seeds e, Seed yield is the seed yield was weighted from the net plot area's thrashed crop through adjusted moisture content of $14 \%$, finally converted into kilograms per hectare

$\mathrm{f}$, Biomass yield is obtained after the whole above ground parts of plant on the net plot area had been harvested at crop maturity it was weighted after during in the sun for three days and converted into kilograms per hectare

g, Straw yield was calculated as a difference of biomass yield and seed yield and converted into kilograms per hectare

$\mathrm{h}$, Harvest index was calculated as ratio of seed yield to biomass

\subsection{Economic Analysis}

Economic analysis was done using the CIMMYT partial budget methodology [48]. The dominance analysis procedure, which was used to select potentially profitable treatments, comprised ranking of treatments in an ascending order of total variable cost from the lowest to the highest cost to eliminate treatments costing more but producing a lower net benefit than the next lowest costing treatment.

The production cost was computed by using the average price of inputs during application season while the average price of faba bean seed was computed based on its price on harvesting season. The variable cost also included the packing material, transportation, labor cost involved in harvesting, threshing and winnowing of the produce as this varied according to the yield obtained from a particular treatment. The cost of each $\mathrm{kg}$ faba bean seed at local market (Yebokla town) during harvesting season was 16.5 birr kg-1 while during the application season the price of lime was 2.50 birr kg-1 . However, the costs of manure and kitchen ash were estimated in terms of its $\mathrm{N}$ content (urea fertilizer) and lime neutralizing value, which were 0.70 and $1.50 \mathrm{birr} \mathrm{kg}^{-1}$, respectively. The cost of labor for harvesting and trashing, was $1.50 \mathrm{Birr} \mathrm{kg}^{-1}$ while cost of 0.20 Birr $\mathrm{kg}^{-1}$ for packaging and transporting. Then by following the CIMMYT partial budget analysis method, the total viable cost, gross field benefit, net benefit and marginal rate of return were calculated. Any treatment with net benefits less than or equal to those of a treatment with lower cost is considered to be dominant. The treatments were arranged in an increasing order of total viable cost to exclude dominantor inferior treatments from analysis of marginal rate of return (MRR) in order to recommend economically profitable treatments [48].

\subsection{Data Analysis}

The collected data were subjected to analysis of variance by following the procedure as in [49] and then analyzed using SAS software version 9.1 [50]. Wherever, the treatment showed a significant effect, Least Significant Difference (LSD) was used for means separation.

\section{Results and Discussions}

\subsection{Phenological Stages of the Crop}

\subsubsection{Days to 50\% Emergence}

The analysis of variance revealed that days to $50 \%$ 
emergence was not affected by main or interaction effects of lime, wood ash and manure $(p>0.05)$. Indeed, seed emergence is largely dependent on the utilization of reserve material and metabolites in the mother tuber [51] and not so much on external factors.

\subsubsection{Days to 50\% Flowering}

Days to $50 \%$ flowering was highly significantly $(\mathrm{p}<0.01)$ affected by main effects of lime and significantly $(\mathrm{p}<0.05)$ affected by manure application but non-significantly influenced by main effect of kitchen ash and all interaction effects (two way and three way interaction effects) of lime, manure and kitchen ash. Days to flowering decreased with increasing rates of lime and manure, zero liming and manuring plots required the longest time to flowering meanwhile, maximum rates resulted in the earliest flowering (Table 1). Lime application on acidic soils reduces toxic $\mathrm{Al}$ concentration and increases the availability of $\mathrm{P}, \mathrm{Ca}, \mathrm{N}$ and therefore enhances plant growth and flowering $[12,52,53,54]$. Similarly, application of manure increases $\mathrm{pH}$ of an acid soil and decreases the solubility of $\mathrm{Al}$, thus it hastens the growth of plants [27].

Table 1. Days to flowering of faba bean as influenced by main effects of lime and manure.

\begin{tabular}{llll}
\hline Lime (t/ha) & Days to flowering & Manure (t/ha) & Days to flowering \\
\hline 0 & $48.1^{\mathrm{a}}$ & 0 & $47.3^{\mathrm{A}}$ \\
1.5 & $46.2^{\mathrm{b}}$ & 2.5 & $46.5^{\mathrm{B}}$ \\
3 & $46.0^{\mathrm{b}}$ & 5 & $46.6^{\mathrm{B}}$ \\
LCR $(0.05)$ & 0.68 & & \\
\hline
\end{tabular}

Means marked with the same letter within a column don't differ statistically at $\mathrm{p}=0.05$

\subsubsection{Days to 50\% Pod Setting}

Days to $50 \%$ pod setting was highly significantly $(\mathrm{p}<0.01)$ affected by main effect of lime while significantly $(\mathrm{p}<0.05)$ influenced by main effect of manure and interaction of lime and kitchen ash. Early pod setting observed on limed plots than un-limed plots, thus liming hastened plant growth. However, the number of days to pod setting was shortened at low application rates of manure (Table 2). However, application of excess $\mathrm{N}$ has resulted to prolonging the growth period of crop, because high application rate of manure supplied more $\mathrm{N}$ manure can contain up to $50-80 \%$ of the $\mathrm{N}$ and $\mathrm{P}$ originally in the feed [55].

Table 2. Days to pod setting affected by main effects of lime and manure.

\begin{tabular}{llll}
\hline Lime (t/ha) & Days to pod setting & Manure (t/ha) & Days to pod setting \\
\hline 0 & $77.8^{\mathrm{b}}$ & 0 & $76.9^{\mathrm{A}}$ \\
1.5 & $76.5^{\mathrm{a}}$ & 2.5 & $76.7^{\mathrm{A}}$ \\
3 & $77.2^{\mathrm{ab}}$ & 5 & $77.8^{\mathrm{B}}$ \\
L CR $(0.05)$ & 0.73 & & \\
\hline
\end{tabular}

Means marked with the same letter within a column don't differ statistically at $\mathrm{p}=0.05$

On the other hand, long days to pod setting was recorded in plots not receiving lime andkitchen ash, while lime and/or kitchen ash application shortened the days to pod setting due to their liming effects to acidic soils (Table 3).
Table 3. Days to pod setting affected by additions of lime and kitchen ash.

\begin{tabular}{llll}
\hline \multirow{2}{*}{ Lime (t/ha) } & \multicolumn{3}{l}{ Kitchen ash (t/ha) } \\
\cline { 2 - 4 } & $\mathbf{0}$ & $\mathbf{0 . 5}$ & $\mathbf{1}$ \\
\hline 0 & $78.9^{\mathrm{A}}$ & $77^{\mathrm{B}}$ & $77.4^{\mathrm{B}}$ \\
1.5 & $76.9^{\mathrm{B}}$ & $76.3^{\mathrm{B}}$ & $76.2^{\mathrm{B}}$ \\
3 & $76.6^{\mathrm{B}}$ & $77.3^{\mathrm{B}}$ & $77.6^{\mathrm{B}}$ \\
L CR $(0.05)$ & 1.27 & & \\
\hline
\end{tabular}

\subsubsection{Days to $90 \%$ Maturity}

Days to $90 \%$ maturity was highly significantly $(\mathrm{p}<0.01)$ affected by main effects of lime and manure while significantly $(\mathrm{p}<0.05)$ influenced by kitchen ash but insignificantly $(p>0.05)$ to all interaction effects of lime, manure and kitchen ash. The crop was matured earlier due to the application of lime, manure and kitchen ash at 1.5, 2.5 and $1 \mathrm{t} /$ ha rate, respectively (Table 4 ).

Table 4. Days of maturity influenced by main effects of lime, manure and kitchen ash.

\begin{tabular}{llllll}
\hline Lime (t/ha) & $\begin{array}{l}\text { Days of } \\
\text { maturity (DM) }\end{array}$ & $\begin{array}{l}\text { Manure } \\
(\mathbf{t} / \mathbf{h a})\end{array}$ & DM & $\begin{array}{l}\text { Kitchen } \\
\text { ash t/ha }\end{array}$ & DM \\
\hline 0 & $152.9^{\mathrm{c}}$ & 0 & $151.0^{\mathrm{A}}$ & 0 & $151.4^{\mathrm{b}}$ \\
1.5 & $148.8^{\mathrm{a}}$ & 2.5 & $149.9^{\mathrm{B}}$ & 0.5 & $151.2^{\mathrm{b}}$ \\
3 & $150.8^{\mathrm{b}}$ & 5 & $151.7^{\mathrm{A}}$ & 1 & $150^{\mathrm{a}}$ \\
LCR (0.05) & 11 & & & & \\
\hline
\end{tabular}

Means marked with the same letter within a column don't differ statistically at $\mathrm{p}=0.05$

\subsection{Growth of the Crop}

\subsubsection{Number of Nodules Per Plant}

Number of nodules on each plant was highly significantly $(\mathrm{p}<0.01)$ affected by main effects of lime and manure only. Maximum nodules were recorded at 1.5 and $2.5 \mathrm{t} / \mathrm{ha}$ lime and manure application, respectively while minimum nodules were observed on lower lime and maximum manure applications (Table 5). Similarly, number of nodules per plant on groundnut was significantly affected by lime rates levels andmaximum nodule number was recorded at $3.7 \mathrm{t} / \mathrm{ha}$ limes application [24].

Table 5. Number of nodules affected by main effects of lime and manure.

\begin{tabular}{llll}
\hline Lime (t/ha) & $\begin{array}{l}\text { No. nodules } \\
\text { per plant }\end{array}$ & $\begin{array}{l}\text { Manure } \\
\text { (t/ha) }\end{array}$ & $\begin{array}{l}\text { No. nodules } \\
\text { /plant }\end{array}$ \\
\hline 0 & $24.9^{\mathrm{b}}$ & 0 & $29.3^{\mathrm{A}}$ \\
1.5 & $34.8^{\mathrm{a}}$ & 2.5 & $32.6^{\mathrm{A}}$ \\
3 & $23.4^{\mathrm{b}}$ & 5 & $21.1^{\mathrm{B}}$ \\
LCR $(0.05)$ & 6 & & \\
\hline
\end{tabular}

Means marked with the same letter within a column don't differ statistically at $\mathrm{p}=0.05$

\subsubsection{Effectiveness of Nodules}

Nodules of white, yellow and green colors are considered ineffective in $\mathrm{N}$ fixation, while pink and slightly red colored nodules are moderately effective but red, brown and dark red nodules are effective in $\mathrm{N}$ fixation. The number of ineffective nodules was significantly $(\mathrm{p}<0.05)$ affected by main effect of manure only but insignificantly by the other effects. However, 
the number of slightly effective and effective nodules were highly significantly $(\mathrm{p}<0.01)$ affected by main effects of lime and manure while insignificantly $(p>0.05)$ influenced by the remaining effects. Minimum nodule number was observed at maximum rate of manure $(5 \mathrm{t} / \mathrm{ha})$ while maximum number of nodules was recorded at low rate of manure (Table 6).

Table 6. The effect of manure on the number of nodules differing in effectiveness for $N$ fixation.

\begin{tabular}{llll}
\hline Manure (t/ha) & $\begin{array}{l}\text { Ineffective } \mathbf{N} \\
\text { fixation }\end{array}$ & $\begin{array}{l}\text { Slightly } \\
\text { effective }\end{array}$ & Effective \\
\hline 0 & $10.4^{\mathrm{a}}$ & $29.7^{\mathrm{A}}$ & $63.3^{\mathrm{a}}$ \\
2.5 & $12.6^{\mathrm{a}}$ & $31.7^{\mathrm{A}}$ & $67.5^{\mathrm{a}}$ \\
5 & $8.7^{\mathrm{b}}$ & $19.6^{\mathrm{B}}$ & $41.9^{\mathrm{b}}$ \\
LCR $(0.05)$ & 3.1 & 7.0 & 14.9 \\
\hline
\end{tabular}

Means marked with the same letter within a column don't differ statistically at $\mathrm{p}=0.05$

On the other hand, $1.5 \mathrm{t} / \mathrm{ha}$ lime highly increased the effectiveness of nodules but their effectiveness was declined with excess application rate (Table 7).

Table 7. The effect of lime on effective nodule number for $N$ fixation.

\begin{tabular}{lll}
\hline Lime (t/ha) & Slightly effective & Effective \\
\hline 0 & $25.6^{\mathrm{B}}$ & $54.1^{\mathrm{b}}$ \\
1.5 & $35.5^{\mathrm{A}}$ & $76.2^{\mathrm{a}}$ \\
3 & $20^{\mathrm{B}}$ & $42.7^{\mathrm{b}}$ \\
$\operatorname{LCR}(0.05)$ & 7 & 14.9 \\
\hline
\end{tabular}

Means marked with the same letter within a column don't differ statistically at $\mathrm{p}=0.05$

\subsubsection{Nodulation Rating}

Nodulation rating was not significantly affected by any of the treatments. Nodulation rating is determined by crop type and climate condition.

\subsubsection{Plant Height}

Plant height was highly significantly $(\mathrm{p}<0.01)$ affected by main effects of lime and manure while insignificantlyaffected by the other effects. This result is consistent with the study conducted in Kenya where it was indicated that rate of wood ash has no significant differences in plant height response [26]. However, with contrast to this finding, application of wood ash has significantly increased plant height of wheat but manure application has had an insignificant effect [25]. All lime treated plots responded with the longest height while zero liming maintained the shortest plant height (Table 8). Thus, liming has favored the growth of plant height. Analogous to this finding, lime application on acidic soils has significantly $(\mathrm{p} \leq 0.001)$ increased the plant height, fresh shoot biomass and dry root biomass of wheat [25]. On the other hand, plant height linearly increased with rate of manure, thus the longest height was obtained by the application of maximum rate of manure while shortest height observed at zero application. Plant height increased by 10 and $13 \%$ over the control treatment through $1.5 \mathrm{t} \mathrm{ha}^{-1}$ lime and $5 \mathrm{t} \mathrm{ha}^{-1}$ manure applications (Table 8).
Table 8. The effects of lime and manure application on plant height.

\begin{tabular}{llll}
\hline Lime (t/ha) & Plant height & Manure (t/ha) & Plant height \\
\hline 0 & $105.1^{\mathrm{b}}$ & 0 & $105.9^{\mathrm{C}}$ \\
1.5 & $115.4^{\mathrm{a}}$ & 2.5 & $111.5^{\mathrm{B}}$ \\
3 & $117^{\mathrm{a}}$ & 5 & $119.9^{\mathrm{A}}$ \\
LCR (0.05) & 4.2 & & \\
\hline
\end{tabular}

Means marked with the same letter within a column don't differ statistically at $\mathrm{p}=0.05$

\subsubsection{Number of Leaves Per Plant}

The number of leaves was significantly $(p<0.05)$ affected by main effect of manure and combined application of manure and kitchen ash but insignificantly $(\mathrm{p}>0.05)$ influenced by other treatments. Number of leaves linearly increased with application rate of manure. Maximum numbers of leaves on each plant was recorded with application of $5 \mathrm{t} \mathrm{ha}^{-1}$ manure. Similarly, number of tef leaves per plant was significantly affected by nitrogen application [56]. On the other hand, maximum number of leaves on each plant (24 leaves) was recorded by combined application of maximum doses of manure $\left(5 \mathrm{tha}^{-1}\right)$ and kitchen ash $\left(1 \mathrm{t} \mathrm{ha} \mathrm{C}^{-1}\right)$. It increased the leaf number by $21 \%$ over zero level of combined manure and kitchen ash treatment (Table 9).

Table 9. Number of leaves in faba beans receiving both manure and kitchen ash.

\begin{tabular}{llll}
\hline \multirow{2}{*}{ Manure (t/ha) } & \multicolumn{3}{l}{ Kitchen ash (t/ha) } \\
\cline { 2 - 4 } & $\mathbf{0}$ & $\mathbf{0 . 5}$ & $\mathbf{1}$ \\
\hline 0 & $19.9^{\mathrm{d}}$ & $21.3^{\mathrm{bc}}$ & $19.4^{\mathrm{cd}}$ \\
2.5 & $20.8^{\mathrm{bcd}}$ & $19^{\mathrm{d}}$ & $20.8^{\mathrm{bcd}}$ \\
5 & $22.2^{\mathrm{ab}}$ & $22.2^{\mathrm{ab}}$ & $24^{\mathrm{a}}$ \\
L CR $(0.05])$ & 1.9 & & \\
\hline
\end{tabular}

Means marked with the same letter don't differ statistically at $\mathrm{p}=0.05$

\subsection{Yield and Yield Component Parameters}

\subsubsection{Number of Pods Per Plant}

Number of pods per plant was highly significantly affected $(p<0.01)$ by interaction effect of lime, manure and kitchen ash -but it was significantly affected $(\mathrm{p}<0.05)$ by main effect of manure and interaction effect of manure and kitchen ash. The maximum number of pods (11) was recorded in plots receiving $2.5 \mathrm{t} /$ ha manure while minimum pods on each plant (9) was observed at zero level manure. Similarly, number of pods per plant was higher where the recommended dose of mineral fertilizer was added, than in limed plots [26]. Liming has also had a significant influence on pod yield of groundnut [24]. Maximum pod number on each plant was recorded in plots receiving 2.5. $\mathrm{t} \mathrm{ha}^{-1}$ manure and $0.5 \mathrm{t} \mathrm{ha}^{-1}$ kitchen ash while minimum pod number was recorded through application of $2.5 \mathrm{t} / \mathrm{ha}$ manure with no kitchen ash. On the other hand, the highest number of pods (14.7) was observed on non-limed, 2.5 $\mathrm{t} \mathrm{ha}^{-1}$ manure and $1 \mathrm{t} \mathrm{ha}^{-1}$ kitchen ash receiving plots but lowest number of pods (6.3) was recorded when no kitchen ash, $3 \mathrm{t}$ lime and $5 \mathrm{t} \mathrm{ha}^{-1}$ manure applied together. However, plots receiving only $1.5 \mathrm{t} \mathrm{ha}^{-1}$ lime or combined with $0.5 \mathrm{t} \mathrm{ha}^{-1}$ kitchen ash (Table 10). 
Table 10. Number of pod per plant by interaction effect of lime, manure and kitchen ash.

\begin{tabular}{lllll}
\hline \multirow{2}{*}{ Lime (t/ha) } & $\begin{array}{l}\text { Manure } \\
\text { (t/ha) }\end{array}$ & \multicolumn{4}{l}{ Kitchen ash (t/ha) } \\
\cline { 3 - 5 } & 0 & $\mathbf{0}$ & $\mathbf{0 . 5}$ & $\mathbf{1}$ \\
\hline \multirow{3}{*}{0} & 2.5 & $7.7^{\text {de }}$ & $10.2^{\text {abcde }}$ & $9.8^{\text {bcde }}$ \\
& 5 & $12.3^{\text {abc }}$ & $11.2^{\text {abcd }}$ & $14.7^{\text {a }}$ \\
& 0 & $9.2^{\text {bcde }}$ & $9.2^{\text {bcde }}$ & $8.2^{\text {cde }}$ \\
1.5 & 2.5 & $10.3^{\text {abcde }}$ & $13.3^{\text {ab }}$ & $15^{\text {bcde }}$ \\
& 5 & $11.33^{\text {abcd }}$ & $7.67^{\text {cde }}$ & $8.7^{\text {bcde }}$ \\
& 0 & $12.2^{\text {abc }}$ & $8.2^{\text {cde }}$ & $7.3^{\text {de }}$ \\
3 & 2.5 & $8.8^{\text {bcde }}$ & $13.3^{\text {ab }}$ & $10.5^{\text {abcde }}$ \\
& 5 & $6.3^{\text {e }}$ & $10.8^{\text {abcde }}$ & $9^{\text {bcde }}$ \\
\hline
\end{tabular}

Means marked with the same letter don't differ statistically at $\mathrm{p}=0.05$

\subsubsection{Pod Length}

The pod length of the crop was significantly affected $(\mathrm{p}<$ 0.05 ) by main effect of manure but insignificantly (p.>0.05) influenced by the other treatments. Application of $2.5 \mathrm{t} / \mathrm{ha}$ manure gave the longest pods while the shortest podswere recorded at zero level manure. Pod length was increased in quadratic fashion through the application of manure (Figure 2) The positive effects of manure application on faba bean growth and yield attributes is due to additional supply of plant nutrients as well as improvement in physical, chemical and biological properties of soil [57].

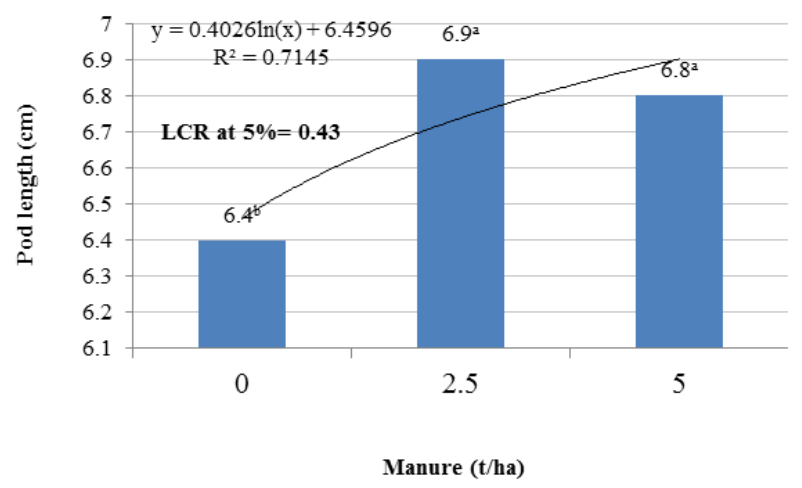

Figure 2. Effect of manure application on pod length of faba bean.

\subsubsection{Number of Pods Per Nod}

Number of pods per nod was in-significantly $(\mathrm{p}>0.05)$ affected by all effects of the experiment. Maximum pods per nod (3) occurred in plots un-limed but received $0.5 \mathrm{t} \mathrm{ha}^{-1}$ kitchen ash and $5 \mathrm{tha}^{-1}$ manure, The number of pods of faba bean has been significantly affected by different rates of NPK-fertilizer.[58].

\subsubsection{Number of Seeds Per Pod}

The number seeds in each pod was significantly $(\mathrm{p}<0.05)$ affected by manure application but the effect by the other treatments wasinsignificant at $p>0.05$. The highest number of seed per pod (3) was recorded at maximum application rate of manure $(5 \mathrm{t} / \mathrm{ha})$ while the lowest seed number (2.7) was observed at $2.5 \mathrm{t} /$ ha manure application (Table 11). In contrary with this, seed number per pod of the soybean has been significantly affected by interaction of lime, Bradyrhizobia and nitrogen fertilizer [59].
Table 11. Effect of manure on number of seeds per pod.

\begin{tabular}{ll}
\hline Manure (t/ha) & Number seeds per pod \\
\hline 0 & $2.8^{\mathrm{ab}}$ \\
2.5 & $2.7^{\mathrm{b}}$ \\
5 & $3^{\mathrm{a}}$ \\
Least Critical Range (0.05) & 0.2 \\
\hline
\end{tabular}

\subsubsection{Hundred Seed Weight}

Hundred seed weight was highly significantly $(\mathrm{p}<0.01)$ affected by main effects of lime, manure and kitchen ash and significantly $(\mathrm{p}<0.05)$ influenced by interaction of lime and manure. Applications of manure and kitchen ash linearly increased the weight of faba bean seeds while excess application of $1.5 \mathrm{t} / \mathrm{ha}$ lime resulted in declined weight of seeds. The percentage of large seeds and 100-seeds weight of groundnut has not generally been affected by $\mathrm{P}$ sources or liming [60]. On the other hand, maximum 100-seeds weight $(66.7 \mathrm{~g})$ was obtained with combined application of $1.5 \mathrm{t}$ lime and $5 \mathrm{t} /$ ha manure, increasing the weight of the seeds by $22 \%$ over the control treatment (Table 12).

Table 12. Hundred seeds weight ( $g$ ) as affected by application of lime and manure.

\begin{tabular}{llll}
\hline \multirow{2}{*}{ Lime (t/ha) } & \multicolumn{3}{l}{ Manure (t/ha) } \\
\cline { 2 - 4 } & $\mathbf{0}$ & $\mathbf{2 . 5}$ & $\mathbf{5}$ \\
\hline 0 & $44.8^{\mathrm{e}}$ & $50.8^{\mathrm{cd}}$ & $54.7^{\mathrm{bcd}}$ \\
1.5 & $50.3^{\mathrm{d}}$ & $59.9^{\mathrm{b}}$ & $66.7^{\mathrm{a}}$ \\
3 & $53.9^{\mathrm{bcd}}$ & $56.7^{\mathrm{bc}}$ & $57.8^{\mathrm{b}}$ \\
L CR $(0.05)$ & 5.5 & & \\
\hline
\end{tabular}

Means marked with the same letter within a column don't differ statistically at $\mathrm{p}=0.05$

\subsubsection{Seed Yield}

Seed yield was highly significantly $(\mathrm{p}<0.01)$ affected by main effect of manure while significantly $(p<0.05)$ influenced by the main effects of lime and kitchen ash and interaction of lime, manure and kitchen ash. The highest seed yields were recorded in plots receiving individual applications of $5 \mathrm{t} \mathrm{ha}^{-1}$ manure, $1.5 \mathrm{t} \mathrm{ha}^{-1}$ lime and $0.5 \mathrm{t} \mathrm{ha}^{-1}$ kitchen ash. Lime and manure applications showed equivalent response (Table 13). Groundnut yield has also been significantly increased by liming due to the availability of calcium [61]. Seed yield of soybean has been significantly affected by the interaction of lime, N and Bradyrhizobia inoculation [59].

Table 13. Effects of manure, lime and kitchen ash on seed yield of faba bean.

\begin{tabular}{llllll}
\hline $\begin{array}{l}\text { Manure } \\
\text { (t/ha) }\end{array}$ & $\begin{array}{l}\text { Seed yield } \\
\text { (kg/ha) }\end{array}$ & $\begin{array}{l}\text { Lime } \\
\text { (t/ha) }\end{array}$ & $\begin{array}{l}\text { Seed yield } \\
\text { (kg/ha) }\end{array}$ & $\begin{array}{l}\text { Kitchen } \\
\text { ash (t/ha) }\end{array}$ & $\begin{array}{l}\text { Seed yield } \\
(\mathbf{k g} / \mathbf{h a})\end{array}$ \\
\hline 0 & $1723^{\mathrm{b}}$ & 0 & $1620^{\mathrm{B}}$ & 0 & $1728^{\mathrm{b}}$ \\
2.5 & $1831^{\mathrm{b}}$ & 1.5 & $2031^{\mathrm{A}}$ & 0.5 & $1921^{\mathrm{a}}$ \\
5 & $2091^{\mathrm{a}}$ & 3 & $1994^{\mathrm{A}}$ & 1 & $1995^{\mathrm{a}}$ \\
LCR (0.05) & 183.7 & & & & \\
\hline
\end{tabular}

Means marked with the same letter within a column don't differ statistically at $\mathrm{p}=0.05$

The highest seed yield $\left(2.59 \mathrm{t} \mathrm{ha}^{-1}\right)$ was obtained at combined $1.5 \mathrm{t}$ lime, $5 \mathrm{t}$ manure and $0.5 \mathrm{t} \mathrm{ha}^{-1}$ kitchen ash while the lowest yield of $1.34 \mathrm{t} \mathrm{ha}^{-1}$ was recorded on control treatment. There were sorts of statistical parity among 
combined $3 \mathrm{t}$ lime, $2.5 \mathrm{t}$ manure and $1 \mathrm{t} \mathrm{ha}^{-1}$ kitchen ash treatment, $3 \mathrm{t}$ lime, zero level manure and $1 \mathrm{t} \mathrm{ha}^{-1}$ kitchen ash and combined zero level lime, $5 \mathrm{t} \mathrm{ha}^{-1}$ manure and $1 \mathrm{t} \mathrm{ha}^{-1}$ kitchen ash treatment (Table 14). The ultimate goal of this study is to improve faba bean seed yield, hence therefore integrated use of $1.5 \mathrm{t}$ lime, $5 \mathrm{t}$ manure and $0.5 \mathrm{t} \mathrm{ha}^{-1}$ kitchen ash gave $1.25 \mathrm{t} \mathrm{ha}^{-1}$ more seed yield over the control treatment.

Table 14. Effect of combined use of manure, lime and kitchen ash on seed yield.

\begin{tabular}{lllll}
\hline Lime & Manur & \multicolumn{4}{l}{ Kitchen ash (t/ha) } \\
\cline { 3 - 5 } (t/ha) & $\mathbf{e}(\mathbf{t} / \mathbf{h a})$ & $\mathbf{0}$ & $\mathbf{0 . 5}$ & $\mathbf{1}$ \\
\hline \multirow{4}{*}{0} & 0 & $1343^{\mathrm{g}}$ & $1435^{\text {fg }}$ & $1481^{\text {fg }}$ \\
& 2.5 & $1528^{\text {defg }}$ & $1620^{\text {cdefg }}$ & $1713^{\text {bcdefg }}$ \\
& 5 & $1759 b^{\text {cdefg }}$ & $1713^{\text {bcdefg }}$ & $1991^{\text {abcdefg }}$ \\
1.5 & 0 & $1531^{\text {abcdef }}$ & $1759^{\text {bcdefg }}$ & $2130^{\text {abcde }}$ \\
& 2.5 & $1736^{\text {bcdefg }}$ & $1991^{\text {abcdefg }}$ & $2083^{\text {abcdef }}$ \\
& 5 & $1944^{\text {abcdefg }}$ & $2593^{\text {a }}$ & $2315^{\text {ab }}$ \\
3 & 0 & $1694^{\text {cdefg }}$ & $1944^{\text {abcdefg }}$ & $1991^{\text {abcdefg }}$ \\
& 2.5 & $1736^{\text {bcdefg }}$ & $2083^{\text {abcdef }}$ & $1991^{\text {abcdefg }}$ \\
L CR $(0.05)$ & 5 & $2083^{\text {abcdef }}$ & $2153^{\text {abcd }}$ & $2268^{\text {abc }}$ \\
\hline
\end{tabular}

Means marked with the same letter don't differ statistically at $p=0.05$

\subsubsection{Straw Yield}

Straw yield was highly significantly affected $(\mathrm{p}<0.01)$ by main effect of manure only. The highest straw yield was obtained at maximum rate of manure $(5 \mathrm{t} / \mathrm{ha})]$ while the lowest straw yield recorded in no manure received plots (Table 15).

Table 15. Effect of manure on straw yield.

\begin{tabular}{ll}
\hline Manure (t/ha]) & Straw yield $\left(\mathrm{kg} \mathrm{ha}^{-\mathbf{1}}\right)$ \\
\hline 0 & $1111.1^{\mathrm{C}}$ \\
2.5 & $1415.6^{\mathrm{b}}$ \\
5 & $1607^{\mathrm{a}}$ \\
Least Critical Range $(0.05)$ & 147 \\
\hline
\end{tabular}

\subsubsection{Biomass Yield}

Biomass yield of the crop was highly significantly $(\mathrm{p}<0.01)$ affected by application of manure while biomass yield was significantly $(p<0.05)$ influenced by lime application. The highest biomass yield was obtained in plots receiving $1.5 \mathrm{t} \mathrm{ha}^{-1}$ lime and $5 \mathrm{tha}^{-1}$ manure meanwhile thelowest at zero levels of manure and lime (Table 16). Similarly, the dry shoot biomass yield of wheat has been significantly increased by application of $3.5 \mathrm{t} \mathrm{ha}^{-1}$ lime and manure $\mathrm{P}$ of $130 \mathrm{~kg} \mathrm{ha}^{-1}$. Application of manure to acid soils increases in soil $\mathrm{pH}$ and decreases $\mathrm{Al}$ solubility and ameliorates Al toxicity, thus increases plant growth in acid soils [27, 62].

Table 16. Main effects of manure and lime application on biomass yield.

\begin{tabular}{llll}
\hline Lime (t/ha) & Biomass yield (kg/ha) & $\begin{array}{l}\text { Manure } \\
(\mathbf{t} / \mathbf{h a})\end{array}$ & $\begin{array}{l}\text { Biomass yield } \\
(\mathbf{k g} / \mathbf{h a})\end{array}$ \\
\hline 0 & $3084^{\mathrm{b}}$ & 0 & $2873^{\mathrm{C}}$ \\
1.5 & $3413^{\mathrm{a}}$ & 2.5 & $3243^{\mathrm{B}}$ \\
3 & $3326^{\mathrm{a}}$ & 5 & $3700^{\mathrm{A}}$ \\
LCR $(0.05)$ & 238 & & \\
\hline
\end{tabular}

Means marked with the same letter within a column don't differ statistically at $\mathrm{p}=0.05$

\subsubsection{Harvest Index}

Harvest index was highly significantly $(p<0.01)$ affected by manure application. The highest harvest index was recorded at zero level manure while the lowest index was observed on higher application rate of manure (Table 17).

Table 17. Application of manure on harvest index of the crop.

\begin{tabular}{ll}
\hline Manure rate (t/ha) & Harvest index (\%) \\
\hline 0 & $61.1^{\mathrm{a}}$ \\
2.5 & $56.5^{\mathrm{b}}$ \\
5 & $56.5^{\mathrm{b}}$ \\
Least Critical Range $(0.05)$ & 0.22 \\
\hline
\end{tabular}

\subsection{Economic Analysis}

The economic analysis results showed that the maximum net benefit of 26,533 birr ha ${ }^{-1}$ with acceptable marginal rate of return (MRR) of $98 \%$ was obtained on combined $1.5 \mathrm{t}$ lime, $0.5 \mathrm{t}$ kitchen ash and $5 \mathrm{t} \mathrm{ha}^{-1}$ manure treatments (Table 18). It was followed by combined $1 \mathrm{t} /$ ha kitchen ash and $5 \mathrm{t} / \mathrm{ha}$ manure treatment which gave a net benefit of 21,516 birr ha ${ }^{-1}$ with MRR of $85 \%$. The return of most treatments increased as crop yield raised due to minimum increment in cost of production when compared with the obtained net returns with an acceptable MRR An increase in output will always raise profit as long as the marginal rate of return is higher than the minimum rate of return $100 \%$ [48].

Table 18. Economic analysis of faba bean.

\begin{tabular}{|c|c|c|c|c|c|}
\hline $\begin{array}{l}\text { Tret } \\
\mathbf{L} * \mathbf{W A} * \mathbf{M}\end{array}$ & $\begin{array}{l}\text { GFBgrain } \\
\text { (Br/ha) }\end{array}$ & $\begin{array}{l}\text { Input cost } \\
\text { (Birr) }\end{array}$ & $\begin{array}{l}\text { TVCBr } \\
\text { /ha }\end{array}$ & $\begin{array}{l}\text { NB } \\
\text { (Br/ha) }\end{array}$ & MRR \\
\hline $0 * 0 * 0$ & 19938 & 0 & 2054 & $17883 \mathrm{D}$ & \\
\hline $0 * 0.5 * 0$ & 21313 & 750 & 2946 & 18367 & 54.2 \\
\hline $0 * 1 * 0$ & 22000 & 1500 & 3767 & $18234 \mathrm{D}$ & \\
\hline $0 * 0 * 2.5$ & 22688 & 1750 & 4088 & 18600 & 20.4 \\
\hline $0 * 0.5 * 2.5$ & 24063 & 2500 & 4979 & 19084 & 54.2 \\
\hline $0 * 1 * 2.5$ & 25438 & 3250 & 5871 & 19567 & 54.2 \\
\hline $0 * 0 * 5$ & 26126 & 3500 & 6192 & 19934 & 114 \\
\hline $1.5 * 0 * 0$ & 25713 & 3750 & 6399 & 19314D & \\
\hline $0 * 0.5 * 5$ & 25438 & 4250 & 6871 & $18567 \mathrm{D}$ & \\
\hline $1.5 * 0.5 * 0$ & 26126 & 4500 & 7192 & 18933D & \\
\hline $0 * 1 * 5$ & 29562 & 5000 & 8046 & 21516 & 85.3 \\
\hline $1.5 * 0 * 2.5$ & 25781 & 5500 & 8156 & $176245 \mathrm{D}$ & \\
\hline $1.5 * 1 * 0$ & 31625 & 5250 & 8508 & 23116 & 346 \\
\hline $1.5 * 0.5 * 2.5$ & 29562 & 6250 & 9296 & $20266 \mathrm{D}$ & \\
\hline $3 * 0 * 0$ & 25162 & 7500 & 10092 & 15069D & \\
\hline $1.5 * 1 * 2.5$ & 30937 & 7000 & 10187 & $20750 \mathrm{D}$ & \\
\hline $1.5 * 0 * 5$ & 28874 & 7250 & 10225 & 18649D & \\
\hline $3 * 0.5 * 0$ & 28874 & 8250 & 11225 & 17649 D & \\
\hline $1.5 * 1 * 5$ & 34375 & 7750 & 11292 & $23083 \mathrm{D}$ & \\
\hline $3 * 0 * 2.5$ & 25781 & 8750 & 11406 & $14375 \mathrm{D}$ & \\
\hline $1.5 * 0.5 * 5$ & 38500 & 8000 & 11967 & 26533 & 98.8 \\
\hline $3 * 1 * 0$ & 29562 & 9000 & 12046 & $17516 \mathrm{D}$ & \\
\hline $3 * 0.5 * 2.5$ & 30937 & 10000 & 13187 & $17750 \mathrm{D}$ & \\
\hline $3 * 1 * 2.5$ & 29562 & 10750 & 13796 & $15766 \mathrm{D}$ & \\
\hline $3 * 0 * 5$ & 30937 & 11000 & 14187 & $16750 \mathrm{D}$ & \\
\hline $3 * 0.5 * 5$ & 31969 & 11750 & 15044 & $16925 \mathrm{D}$ & \\
\hline $3 * 1 * 5$ & 33687 & 12500 & 15971 & $17716 \mathrm{D}$ & \\
\hline
\end{tabular}

\subsection{Correlation Analysis}

Days to flowering was positively and significantly associated with days to pod setting $(r=0.45)$ and maturity 
$(\mathrm{r}=0.3)$ but positively and significantly associated to plant height $(\mathrm{r}=-0.36), 100$ seeds weight $(\mathrm{r}=-0.29)$, seed $(\mathrm{r}=-0.27)$, straw $(\mathrm{r}=-0.29)$, and biomass $(\mathrm{r}=-0.32)$ yields. Plant height was positively and significantly correlated to seed $(\mathrm{r}=-0.25)$, straw $(\mathrm{r}=0.37)$ and biomass $(\mathrm{r}=0.39)$ yield. This result agreed with the finding of an earlier report [63] where plant height correlated positively with seed, straw and biomass yield.
However, number of nodules per plant was negatively and significantly correlated to straw $(\mathrm{r}=-0.23)$ and biomass $(\mathrm{r}=-0.23)$ yield. Seed yield was positively and significantly associated to hundred seeds weight $(\mathrm{r}=0.33)$, straw $(\mathrm{r}=0.27)$, biomass $(\mathrm{r}=0.85)$ and harvest index $(\mathrm{r}=0.53)$ (Table 19). Similarly, seed yield of groundnut has associated positively and significantly with the harvest index of the crop [64].

Table 19. Correlation coefficients of the crop parameters.

\begin{tabular}{|c|c|c|c|c|c|c|c|c|c|c|c|c|c|c|c|c|c|c|}
\hline & DE & DF & DPS & DM & $\mathbf{P H}$ & NNPP & NENN & SENN & ENN & NPPP & PL & NPPN & NLPP & NSPP & HSW & GY & SY & BY \\
\hline$\overline{\mathrm{DF}}$ & -0.05 & & & & & & & & & & & & & & & & & \\
\hline DPS & -0.07 & $0.45^{* *}$ & & & & & & & & & & & & & & & & \\
\hline DM & -0.06 & $0.30 *^{*}$ & $0.27^{* *}$ & & & & & & & & & & & & & & & \\
\hline PH & -0.06 & $-0.36^{* *}$ & -0.02 & $-0.28^{*}$ & & & & & & & & & & & & & & \\
\hline NNPP & -0.09 & -0.03 & $-0.24^{*}$ & $-0.23^{*}$ & -0.13 & & & & & & & & & & & & & \\
\hline NENN & -0.01 & 0.01 & -0.05 & -0.15 & -0.02 & $0.74^{* *}$ & & & & & & & & & & & & \\
\hline SENN & -0.09 & -0.03 & $-0.32^{* *}$ & -0.18 & -0.16 & $0.89^{* *}$ & $0.41^{* *}$ & & & & & & & & & & & \\
\hline NPPP & 0.16 & -0.05 & $-0.22^{*}$ & $-0.23^{*}$ & 0.03 & 0.02 & -0.0 & $0.59^{* *}$ & -0.05 & & & & & & & & & \\
\hline PL & 0.02 & -0.2 & -0.02 & -0.14 & 0.12 & -0.01 & 0.06 & -0.04 & -0.06 & $0.39^{* *}$ & & & & & & & & \\
\hline NPPN & 0.05 & -0.05 & -0.2 & -0.17 & -0.01 & 0.12 & 0.05 & 0.16 & 0.05 & $0.62^{* *}$ & 0.16 & & & & & & & \\
\hline NLPP & $-0.26^{*}$ & -0.22 & 0.00 & -0.03 & $0.33^{* *}$ & -0.14 & $-0.24^{*}$ & -0.09 & 0.09 & -0.03 & 0.18 & -0.06 & & & & & & \\
\hline NSPP & -0.11 & -0.19 & 0.02 & -0.05 & 0.19 & -0.19 & $-0.24^{*}$ & -0.12 & -0.04 & -0.08 & $0.24^{*}$ & -0.08 & $0.31^{* *}$ & & & & & \\
\hline HSW & -0.08 & $-0.29^{* *}$ & -0.08 & -0.36 & $0.54^{* *}$ & -0.11 & -0.15 & -0.09 & 0.09 & 0.01 & 0.04 & 0.08 & $0.38^{* *}$ & 0.11 & & & & \\
\hline GY & $-0.27^{*}$ & $-0.27^{*}$ & 0.06 & -0.04 & $0.25^{*}$ & -0.15 & 0.02 & -0.19 & -0.18 & -0.05 & 0.1 & -0.03 & 0.21 & 0.21 & $0.35^{* *}$ & & & \\
\hline SY & $-0.24^{*}$ & $-0.29^{* *}$ & -0.02 & 0.06 & $0.37^{* *}$ & $-0.23^{*}$ & -0.15 & -0.17 & $-0.24^{*}$ & 0.05 & 0.17 & 0.19 & 0.19 & 0.11 & $0.26^{*}$ & $0.27^{*}$ & & \\
\hline HI & -0.00 & 0.09 & 0.00 & -0.5 & -0.18 & 0.09 & 0.15 & 0.02 & 0.09 & -0.1 & -0.06 & -0.19 & -0.03 & 0.08 & 0.00 & $0.53^{* *}$ & $-0.68^{* *}$ & -0.0 \\
\hline
\end{tabular}

$\mathrm{DE}=$ Days to Emergence, $\mathrm{DF}=$ Days to Flowering, DPS= Days to Pod Setting, DM= Days to Maturity, PH= Plant Height, NNPP= Number of Nodules Per Plant, $\mathrm{NENN}=$ Non-Effective Nodule Number, SENN= Slightly Effective Nodule Number, ENN= Effective Nodule Number, NPPP= Number of Pods Per Plant, PL= Pod Length, NPPN= Number of Pods Per Nod, NLPP $=$ Number of Leaves Per Plant, NSPP $=$ Number of Seeds Per Pod, HSW= Hundred Seeds Weight, GY= Seed Yield, $\mathrm{SY}=$ Straw Yield, BY= Biomass Yield, HI= Harvest Index, $* *=$ Significant at $\mathrm{p}<0.01$ and $*=$ Significant at $\mathrm{p}<0.05$.

\section{Conclusion and Recommendation}

Most cultivated lands of Amhara National Regional State are characterized by high acidity and nutrient depletion. Ameliorating these soils can increase the productivity of crop. Most farmers in the study area are small-scale and resource poor, therefore integrating use local available liming materials such as manure and kitchen ash with lime has great advantages and is highly applicable in the area. However, meager information is available about its effects based on the empirical studies to adopt the practice in the study area.

Lime and manure application significantly hastened flowering, pod setting and maturity of faba bean while kitchen ash application had an insignificant effect to most crop phenological stages. Nodulation of the crop was significantly affected by application of lime and manure. Maximum nodule numbers were recorded at $1.5 \mathrm{t} /$ ha lime and $2.5 \mathrm{t} /$ ha manure application but their number declined with excess rates of lime and manure. Similarly, the effectiveness of nodules increased through. $5 \mathrm{t}$ lime and $2.5 \mathrm{t} /$ ha manure application. Plant heights significantly increased by $1.5 \mathrm{t}$ lime and $5 \mathrm{t} / \mathrm{ha}$ manure application. Maximum number of pods was obtained upon combined use of $2.5 \mathrm{t}$ manure and $1 \mathrm{t} /$ ha kitchen ash, while manure application increases the length of pod. The highest number of seeds per pod was recorded on $5 \mathrm{t} / \mathrm{ha}$ manure. Seed yield was significantly affected by individual effects of lime, manure and kitchen ash and by their combined application of
$1.5 \mathrm{t}$ lime, $5 \mathrm{t}$ manure and $0.5 \mathrm{t} / \mathrm{ha}$ kitchen ash gave $1.25 \mathrm{t} / \mathrm{ha}$ $(22 \%)$ more yield over the control treatment. Straw and biomass yields were significantly increased at maximum rate of manure.

The economic analysis showed that combining use of $1.5 \mathrm{t}$ /ha lime, $0.5 \mathrm{t} /$ ha kitchen ash and $5 \mathrm{tha}^{-1}$ manure management gave maximum net profit of 26,533 Birr/ha with marginal rate of return of $98 \%$. This treatment gave additional profit of 8650 Birr/ha over the control treatment. Thus, integrating use of 1.5 $\mathrm{t}$ lime, $5 \mathrm{t}$ manure and $0.5 \mathrm{t} / \mathrm{ha}$ kitchen ash to faba bean increases the production and profit in Gozamin district.

\section{Acknowledgements}

The authors express their deepest thanks to Debre Markos University for funding this study.

\section{References}

[1] Yamane A. and Skjelvag O. Effects of fertilizer phosphorus on yield traits of Dekeko (Pisum sativum L) under field conditions. Journal of Crop Science, 2003, 189: 14-20.

[2] MOAFDRE. Manual for pulse crop package, Amharic version. Published through joint cooperation of ATA, EIAR. 2015. pp 91-114. Addis Ababa, Ethiopia.

[3] Rubiales D. Faba beans in sustainable agriculture. Field Crops Research, 2010. 115: 201-202. 
[4] Habtemichial K., Singh B. and Aune J. Wheat response to N fixed by faba bean (Vicia faba L.) as affected by sulfur fertilization and rhizobial inoculation in semi arid Northern Ethiopia. Journal of Plant Nutrition and Soil Sciences, 2007. 170: 412-418.

[5] CSA. The Federal Democratic Republic of Ethiopia Central Statistical Agency. Agricultural sample survey, volume I. Report on area and production of major crops (private peasant holdings, 2012/13 Meher season). Statistical bulletin 532, Addis Ababa, Ethiopia, 2013.

[6] CSA. The Federal Democratic Republic of Ethiopia Central Statistical Agency. Agricultural sample survey, volume I, report on area and production of major crops (private peasant holdings, 2014/15 Meher season), statistical bulletin 578, Addis Ababa, Ethiopia. 2015.

[7] Paulose Dubale. Northeast African Studies, (ISSN] 0740-9133) 2001. Vol. 8, No. 1, pp. 27-52. Quintero, C. E. Boschetti, N. G. and Benavidez, R. A. (2003). Effect of soil buffer capacity on soil test phosphorus interpretation and fertilize requirement. Communications in Soil Science and Plant Analysis, 34: 14351450. DOI: $10.1081 /$ CSS-120020455.

[8] Fassil Kebede and Charles Y. Soil fertility status and mass fertilizer recommendation of Typic Hapluusterts in the northern highlands of Ethiopia. World Applied Sciences Journal, 2009. 6: 1473-1480.

[9] Tekalign Mammo, Hague, I. and Kamara, C. Phosphorus status of some Ethiopian highland Vertisol. 232-242. In: Jutz, S. Hague, F. Mcintric (eds.). Soil in Sub-Sahara Africa, ILCA, 1988. Addis Ababa, Ethiopia.

[10] Mesfin Abebe/Nature and management of acid soils in Ethiopia. Addis Ababa, Ethiopia, 2007.

[11] Solomon Dawit, Lehmann, J. Tekalign Mammo, Fritzsche, F. and Zech, W.. Phosphorus forms and dynamics as influenced by land use changes in the sub-humid Ethiopian highlands. Geoderma, 2002. 105: 21-48.

[12] Upjohn, B. Fenton, G. and Conyers, M. Soil acidity and liming. Agfact AC. 19, $3^{\text {rd }}$ edition AGDEX 534, State of New South Wales, Wagga Agricultural Institute. 2005.

[13] Kisinyo, P. Opala, P. Gudu, S. Othieno, C. Okalebo, J. Palapala, $\mathrm{V}$. and Otinga, A. Recent advances towards understanding and managing Kenyan acid soils for improved crop production. African Journal of Agricultural Research. 2014. Vol 9, pp. 297 -2408 .

[14] IOANRS. 2006. Potential Survey, Identification of Opportunities and Preparations of Projects Profiles and Feasibility Studies. Part one potential assessment, unpublished soil survey study report by Development Studies Association and Shawel Consult International.

[15] Godara A. S., Gupt U. S. and Singh R. Effect of integrated nutrient management on herbage, dry fodder yield and quality of oat. Forage Research, 2012. 38 (1): 59-61.

[16] Diacono M., Rubino P. and Montemurro F. Precision nitrogen management of wheat a review. Agronomy for Sustainable Development, 2013.33 (1): 219-241.

[17] Whitehead, D. C. Nutrient elements in grassland soil-plantanimal relationships. Department of Soil Science, Institute for Grassland and Environmental Research. CABI Publishing, Oxon and New York, UK and USA. 2000.
[18] Quintero, C. Boschetti, N. and Benavidez, R. Effect of soil buffer capacity on soil test phosphorus interpretation and fertilize requirement. Communications in Soil Science and Plant Analysis, 2003. 34: 1435-1450. doi: $10.1081 /$ CSS-120020455

[19] Fageria, N The use of nutrients in crop plants, CRC Press Taylor \& Francis Group LLC. CRC Press is an imprint of Taylor \& Francis Group, an Information business. 2009. ISBN 13: 978-1-4200-7510-6 United States of America.

[20] Taye Bekele, Zebene Mikru and Abayneh Esayas.. Laboratory procedure for thedetermination of lime requirement and calcium carbonate content in lime. National Soil Research Center Ethiopian Institute of Agricultural Research, unpublished laboratory manual. 2007.

[21] Agegnehu Getachew and Fessehaie R. Response of faba bean to phosphate fertilizer and weed control on Nitisols of Ethiopian highlands. Italian Journal of Agronomy, 2006. 2: 281-290.

[22] Negi, S. Singh R. and Dwivedi. O. Effect of biofertiuzers, nutrient sources and lime on growth and yield of garden pea. Legume Research, 2006. 29: 282-285.

[23] Kisinyo, P. Gudu S. Othieno C. Okalebo J. and Opala P. Effects of lime, phosphorus and rhizobia onSesbania sesban performance in a Western Kenyan acid soil. African. Journal Agriculture Research, 2012.7: 2800-2809..

[24] Rajkishore, R. 2005. Response of groundnut genotypes to lime and phosphorus levels in coastal alluvial soil of north Karnataka. MSc. Thesis, Dharwad Universityof Agricultural Sciences, India.

[25] Asmare Melese, Yli-HallaM. and Birru Yitaferu. Effects of Lime, Wood Ash, Manure and Mineral P Fertilizer Rates on Acidity Related Chemical Properties and Growth and P Uptake of Wheat (Triticum aestivum L.) on Acid Soil of Farta District, Northwestern Highlands of Ethiopia. International Journal of Agriculture and Crop Sciences. 2015, 8; 256-269.

[26] Wiklund, J. Effects of wood ash on soil fertility and plant performance in southwestern Kenya. An MSc thesis Department of Soil and Environment, Faculty of Natural Resources and Agricultural Sciences, Swedish University of Agricultural Sciences, Uppsala, http://stud.epsilon.slu.se, 2017.

[27] Whalen, J., Chang C., Clayton G. and Carefoot J. Cattle manure amendments can increase the $\mathrm{pH}$ of acid soils. Soil Science Society of America Journal. 2000. 64, 962-966.

[28] Naramabuye, F. Haynes, R. and Modi, A. Cattle manure and grass residues as liming materials, in a semi-subsistence farming system. Agriculture, Ecosystems and Environment, 2008. 124: 136-141. doi: 10.1016/j.agee.2007.08.005.

[29] Acharya, C. Integrated input management for sustainable crop production in rain fed agroecosystem. Journal of the Indian Society of Soil Science, 50: 398-413.

[30] MoARD. Crop Development Department. Issue No. 8. Addis Ababa, Ethiopia. 2005.

[31] Bureau of Agriculture. 1999. Agricultural Master Plan of the Amhara National Regional State Technical report on soil and water management, Bahir Dar, Ethiopia. 
[32] Mekonnen Asrat, Heluf Gebrekidan, Yli-Halla M., Bobe Bedadi and Wakene Negassa. Effect of integrated use of lime, manure and mineral $\mathrm{P}$ fertilizer on bread wheat (Triticum aestivum $\mathrm{L}$.) yield, uptake and status of residual soil $\mathrm{P}$ on acidic soils of Gozamin District, Northwestern Ethiopia. Agriculture, Forestry and Fisheries, 2014. 3 (2): 76-85.

[33] Vance, E. D., Land application of wood-fired and combination boiler ashes: An overview. Journal of Environmental Quality. 1996. 25: 937-944.

[34] Day, P. Hydrometer method of particle size analysis. In: Black C. (ed.). Methods of soil analysis. Agronomy Part I, No. 9. American Society of Agronomy. Madison, Wisconsin, USA. 1965.

[35] Walkley, A. and Black C. A., An examination of different methods for determining soil organic matter and the proposed modification by the chromic acid titration method. Soil Sciences 1934. 37: 29-38p.

[36] Jackson, M. L. 1967. Soil Chemical Analysis. Prentice-Hall of India, New Delhi.

[37] Olsen, S. R., C. V. Cole, Watanabe F. S. and Dean L. A. 1954. Estimation of Available Phosphorus in Soils by Extraction with Sodium Bicarbonate. U. S. Department of Agriculture Circular No. 939. Banderis, A. D., D. H. Barter and K. Anderson.

[38] Murphy, J. and J. P. Riley. A modified single solution method for the determination of phosphate in natural waters. Analytical Chemical. Acta. 1962. 27: 31-36.

[39] Sahlemedhin Serstu and Taye Bekele. Procedure for soil and plant analysis. National Soil Research Centre, Ethiopian Agricultural Research Organization, Addis Ababa, Ethiopia. 2000 .

[40] Rowell, D. L.. Soil science: Methods and applications. Addison Wesley Longman Limited England. 1994350pp.

[41] Matthews, P. and Marcellos T. 2003. Faba bean. Ag fact P 4.2.7. Second edition, 1-24. Mba, C. N. Influence of organic wastes on plant growth parameters and nutrient uptake by maize (Zea mays L). Nigerian Journal of Soil Science, 2006. 16: 104-108.

[42] Hazelton, P. and Murphy B. Interpreting Soil Test Results What Do All The Numbers Mean? $2^{\text {nd }}$ ed. Csiro Publishing. ISBN 978064309225 9, Collingwood, Australia. 2007.

[43] Landon. J. R. Booker Tropical Soil Manual: a handbook for soil survey and agricultural land evaluation in the tropics and subtropics. (ed.) John Wiley \& Sons Inc., New York. 1991.

[44] Tekalign Tadesse. Soil, plant, water, fertilizer, animal manure and compost analysis. Working Document NO 13. ILCA, Addis Ababa, Ethiopia. 1991.

[45] Bougnom, B. P., Knapp B. A., Etoa F-X. and Insam H. Possible use of wood ash and compost for improving acid tropical soils. In: Insam, H., and Knapp B. A (eds.) Recycling of biomass ashes. Springer-Verlag, Berlin Heidelberg. 2011. Pp. 87 - 105.

[46] FAO (Food and Agriculture Organization). 2007. Methods of Analysis for Soils of Arid and Semi-arid Regions. Edited by Issam I. Bashour and Antoine H. Sayegh. Rome, Italy.

[47] NifTAL. International Network of Legume Inoculation Trials. NifTAL project, University of Hawaii, College of Tropical Agriculture and Human Resource, USAID. Honolulu 1979..

[48] CIMMYT.. Economics program, from agronomic data to farmer recommendations: an economics training manual. 1988, No. 27.

[49] Gomez K. A. and Gomez A. A. Statistical Procedures for Agricultural Research. 2nd Edition. John Wiley and Sons Inc. Inter-Science Publications. New York. 1984. pp. 180-225.

[50] SAS (Statistical Analysis Software).. SAS/STAT guide for personal computers, version 9.1 edition. SAS Institute Inc., Cary, North Carolina, USA. 2003

[51] Kabir, M., Alam M., Hossain, M., Hossain, M. and Hossain, M. J. Yield performance of whole-tuber and cut-piece planting of potato. Tropical Science, 2004. 44: 16-19.

[52] IFPRI 2010. Fertilizer and Soil Fertility Potential in Ethiopia, Constraints and Opportunities for Enhancing the System. Sustainable solution for ending hanger and poverty Contributed by Gete Zelleke, Getachew Agegnehu, Dejene Abera, Shahid, R. Working paper, pp 1-66. (http://www.ifpri.org.) Accessed on July 6,2012

[53] Andric, L. Rastija, M. Teklic, T. and Kovacevic, V. Response of maize and soybeans to liming. Turkish journal of agriculture and forestry. 2012. 36: 415-420.

[54] Abebe Zerihun and Tolera Abera. Yield response of faba bean to fertilizer rate, rhizobium inoculation and lime rate at Gedo highland, western Ethiopia. Global Journal of Crop, Soil Science and Plant Breeding, 2014., 2: 134-139.

[55] Malley, D., McClure C., Marti P., Buckley K. and McCaughey W. Compositional analysis of cattle manure during composting using a field-portable near-infrared spectrometer. Taylor and Francis, Inc. ISSN 0010-3624. DOI 10.1081/CSS-200043187. Communications in Soil Science and Plant Analysis, 2005. 36: 455-475.

[56] Murtada Yousef.. Effect of Seed Rate and Nitrogen on Growth and Yield of Teff Grass [Eragrostis teff (Zucc.) Trotter). An MSc thesis, University of Khartoum. Khartoum, Sudan. 2004.

[57] Datt, N., Sharma R. and Sharma G. Effect of supplementary use of FYM along with chemical fertilizers on productivity and nutrient uptake by vegetable pea and build up of soil fertility in Lahul Valley. Indian Journal of Agricultural Science, 2003. 73: 266-68.

[58] Hanan S., Samia H., Mona G., and Awatef A. Partial Replacement of Integrated Mineral Fertilizer through Bio fertilization to Maximize Economic Yield of Faba Bean under Saline Soil Conditions. Intentional Journal of Chem. Tech. Research. 2016. 9 (6): 153-164.

[59] Workneh Bekere. Liming Effects on Yield and Yield Attributes of Nitrogen Fertilized and Bradyrhizobia Inoculated Soybean (Glycine max L.) Grown in Acidic Soil at Jimma, South Western Ethiopia. Journal of Biology, Agriculture and Healthcare.

[60] Nakagawa J. Imaizumi I. and RossetoC. Effects of some phosphorus sources and of liming on groundnut seed quality. Pesquisa Agropecuaria Brasileria, 1990. 25 (4): 505-512 pp

[61] Gogoi, P. K., Chaudhury, R. M., Dutta, R. and Deka, N. C. Effect of levels of lime and nitrogen on production of groundnut. Crop Research, 2000. 20: 274-278

[62] Mokolobate, M. and Haynes R. Comparative liming effect of four organic residues applied to an acid soil. Biology Fertilizers of Soils, 2002. 35, 79-85. 
[63] Addisu Ebbisa. Effects of NPS and bio-organic fertilizers on yield and yield components of faba bean (Vicia faba L.) in Gozamin District,, An MSc thesis Department of Plant Sciences, Collage of Agriculture and Natural Resources, Debre Markos University. 2017.
[64] Vaithiyalingan, M., Manoharan V. and Ramamoorthi N. Association analysis amongthe yield and yield attributes of early season drought tolerant groundnut (Arachis hypogaea L.). Journal of Plant Breeding, 2010. 1 (5): 1347-1350. 